\title{
ARTIFICIAL INTELLIGENCE DALAM PENANGANAN KOMPLAIN PELANGGAN PADA INDUSTRI COATING
}

\author{
Langgeng Listiyoko ${ }^{1}$ \\ Listina Nadhia $\mathrm{N}^{2}$ \\ Indri Handayani ${ }^{3}$

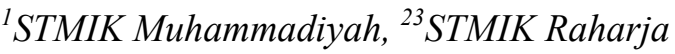 \\ Email : langgeng.listiyoko@,raharja.info ${ }^{1}, \underline{\text { listina.nadhia@raharja.info }}{ }^{2}, \underline{\text { indri@raharja.info }}^{3}$
}

\begin{abstract}
Many company are now thinking about how to maintain their customer well. It's not only to keep customer's loyality but having much more customer is a big challenge. Normally potential customer looking for a good reputation company by their customer care availability. Once customer getting a problem then the complaint handler must be in charge. The way solving the problem will be considered to decide to reorder or not. Information technology come as a system to help people establish their own customer complaint handler. By implementing Artificial Intelligence the efficiency of overall problem solving activity will be achieved rapidly. One of suitable method in data mining concept in order to establish this system is CART (Classification And Regression Trees). Historical data is prepared by each branch from many place that create the datawarehouse. Then knowledge base wisely managed by knowledge engineer who transfering knowledge into the system.
\end{abstract}

Keyword : customer complaint handler, artificial intelligence, CART, datawarehouse, knowledge base, knowledge engineer

\begin{abstract}
ABSTRAK
Banyak perusahaan saat ini memikirkan cara untuk memelihara hubungan baik mereka dengan para pelanggannya. Bukan hanya masalah loyalitas, meraih lebih banyak pelanggan juga menjadi tantangan besar. Calon pelanggan mencari perusahaan dengan reputasi yang bagus dengan cara melihat keberadaan customer care atau layanan pelanggan. Apabila terjadi masalah / komplain maka tim inilah yang selanjutnya bertanggung jawab. Bagaimana tim ini bekerja menyelesaikan masalah akan menjadi pertimbangan khusus untuk pelanggan apakah akan melakukan transaksi selanjutnya atau tidak. Teknologi informasi berperan dalam membangun sistem ini yaitu dengan implementasi Artificial Intelligence. Salah satu metode dari konsep data mining yang sesuai adalah pohon keputusan CART (Classification And Regression Trees). Diperlukan data latihan yang diperoleh dari setiap cabang untuk selanjutnya digunakan perekayasa pengetahuan untuk membangun knowledge base.
\end{abstract}

Kata kunci : customer complaint handler, artificial intelligence, CART, datawarehouse, knowledge base, knowledge engineer 


\section{Pendahuluan}

Sebuah perusahaan yang memberikan layanan purna jual sebagai value preposition tentu mengharapkan tersedianya sebuah sistem yang efektif. Beberapa alasan mengapa customer enggan menggunakan produk dari produsen tertentu antara lain adalah karena masalah kualitas dan layanan. Customer Complaint Handler adalah bentuk nyata dari usaha membangun sistem pelayanan pelanggan berkenaan dengan kualitas produk. Umumnyaa pelanggan akan lebih bisa menerima produk setelah melihat adanya jaminan berupa Customer Complaint Handler (CCH).

Customer Care atau layanan pelanggan sudah merupakan kebutuhan pokok bagi produsen/ pelaku industri dengan cakupan layanan yang lebih luas dari $\mathrm{CCH}$. Sebagai organisasi yang secara khusus menangani komplain/ keluhan, $\mathrm{CCH}$ memainkan pula peran penyelesaian masalah, investigasi, analisa, dan menentukan langkah pencegahan terulangnya masalah serupa. Oleh karenanya $\mathrm{CCH}$ memiliki akses yang cukup luas kepada unit - unit terkait untuk berkoordinasi sejak proses perencanaan, produksi, distribusi, bahkan pengembangan produk. $\mathrm{CCH}$ dibekali kemampuan menganalisa dan mengidentifikasi masalah sehingga dapat melakukan penanganan yang tepat sasaran. Erat kaitannya keberadaan $\mathrm{CCH}$ dengan departemen Quality Control (QC).

Pada sistem konvensional, kegiatan $\mathrm{CCH}$ dilakukan oleh tenaga ahli (technical) dalam rangka melaksanakan tugas investigasi lapangan dan identifikasi masalah. Dengan demikian dapat didefinisikan masalah yang sebenarnya timbul. Hal ini perlu sebab banyak dijumpai adanya perbedaan persepsi dalam istilah - istilah yang bersifat teknis. Investigasi dilakukan salah satunya untuk menyamakan persepsi antara pelanggan dan produsen. Maka sebagai tenaga ahli harus mampu membawa hasil investigasinya ke laboratorium untuk didiskusikan dengan peneliti dengan persepsi yang benar.

Pekerjaan investigasi akan menjadi kompleks manakala dihadapkan pada jenis produk yang berbeda, kondisi lingkungan yang berbeda, dan pengetahuan pelanggan yang berbeda pula. Di lain sisi masing - masing produk memiliki karakter dan cara penanganan yang unik. Hal ini kemudian mendorong terlaksananya sistem yang terdistribusi. Tim kerja yang solid dibutuhkan untuk menopang komunikasi internal dan eksternal demi tercapainya perbaikan atau pengembangan produk, terlebih jika diperlukan analisa yang berkesinambungan.

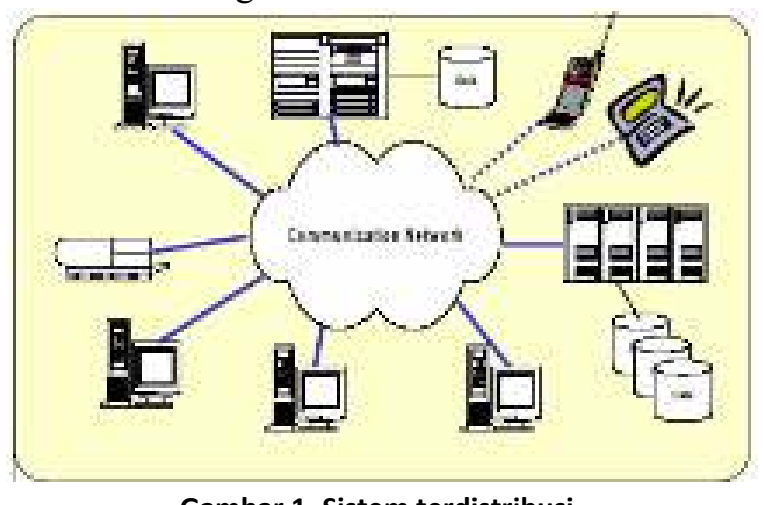

Gambar 1. Sistem terdistribusi

Pada umumnya saat ini perusahaan telah memiliki modal awal membangun sistem yang saling berinteraksi dengan berbagai jenis device dan sistem independen. Kantor - kantor cabang yang letaknya saling berjauhan dapat memiliki lingkungan kerja sendiri yang terpisah satu sama lain. Namun dalam beberapa kesempatan mereka dapat saling bertukar informasi. Contoh paling sedeerhana adalah misalnya dengan terlaksananya teleconference. Atau penerapan IP Phone yang memungkinkan penghematan biaya komunikasi. Sistem independen yang terhubung melalui jaringan komputer dan dilengkapi software serta berinteraksi satu sama lain disebut sistem terdistribusi seperti diilustrasikan pada gambar 1. 


\section{Permasalahan}

Perusahaan berskala nasional memiliki cabang - cabang di berbagai kota. Masing masing daerah memiliki karakter lingkungan yang cenderung berbeda, khususnya dalam hal kompatibilitas produk coating. Latar belakang budaya ikut berpengaruh pada customer requirement sehingga produsen harus memikirkan produk yang bersifat universal di samping tentu produk yang unik.

Produk unik ataupun universal tetap membutuhkan dukungan teknis yang tepat. Hanya saja pada produk - produk yang bersifat universal lebih bisa dikontrol yang memungkinkan penanganan atas produk dan kasus yang sama cepat diselesaikan. Jika para tenaga ahli yang ada di setiap daerah mampu menyelesaikan masalah / komplain yang timbul dengan efektif, maka secara regional database mengenai masalah - masalah yang ada dapat dibangun. Dengan demikian langkah selanjutnya dapat dibangun sebuah sistem penunjang keputusan berbasis teknologi informasi dan bahkan dapat terwujud kecerdasan buatan. Kecerdasan buatan pada dasarnya adalah memindahkan pengetahuan manusia ke dalam sistem komputer, yang artinya pada waktu membangun database dengan sendirinya sistem komputer telah menerima pengetahuan awal mengenai data - data yang diperlukan.

Tidak demikian pada sistem layanan pelanggan konvensional yang cenderung bergantung pada arsip hardcopy. Metode ini akan lebih rumit jika terjadi pergantian personil atau kebijakan non teknis lainnya yang dapat menyebabkan biasnya data.

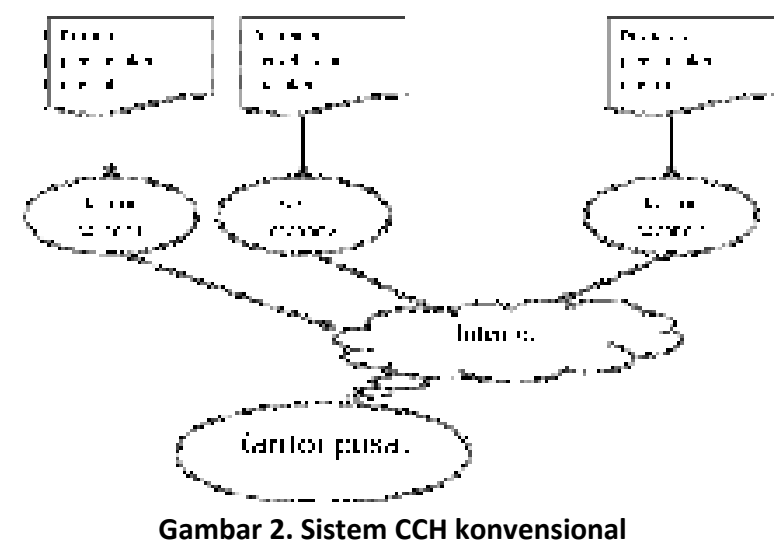

Dari gambar 2 dapat dijelaskan bahwa komunikasi kantor cabang ke kantor pusat dilakukan dengan memanfaatkan jaringan internet. Namun tidak ada komunikasi antar kantor cabang, yang artinya setiap cabang memilki database masing - masing di setiap server. Peluang terjadinya duplikasi masalah sangat besar. Pertukaran data antara kantor cabang dan kantor pusat pun tidak bisa dilakukan secara langsung. Data retrieval dilakukan oleh kantor cabang untuk selanjutnya diteruskan ke kantor pusat. Ini tidaklah efisien. Gagasan yang lebih rasional adalah dengan memusatkan data ke kantor pusat sekaligus memberikan akses langsung kepada data tersebut sehingga seluruh kantor cabang yang ada dapat mengakses dengan cepat. Ilustrasi tentang gagasan ini seperti ditunjukkan pada gambar 3 berikut ini.

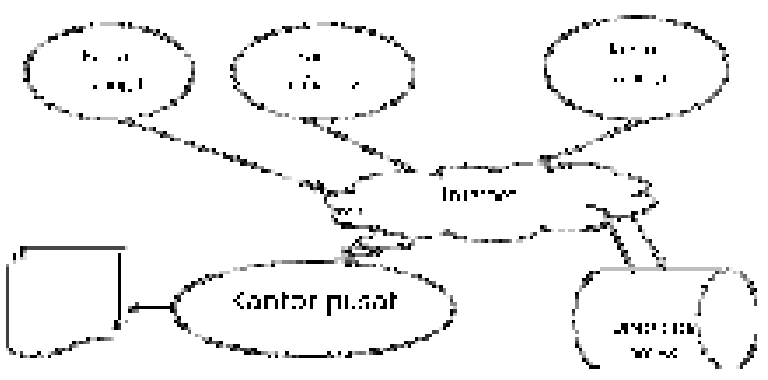

Gambar 3. Akses data langsung

Dampak yang paling mengkhawatirkan pada sistem konvensional selain masalah 
pergantian personil adalah data retrieve yang seharusnya dapat mempersingkat proses analisa dan pengambilan keputusan, khususnya penanganan jangka pendek (quick action). Tanpa adanya bantuan sistem komputer maka bukan tidak mungkin akan terjadi overlaping atau looping yang justeru akan membuat pekerjaan tidak efektif. Atau kemungkinan terjadinya masalah / komplain yang berulang oleh karena tidak adanya kontrol tentang penerapan tindakan pencegahan yang telah disepakati.

Banyak kerugian yang ditimbulkan dengan sistem penanganan komplain yang masih konvensional ini antara lain :

1. Terjadi pemborosan waktu

Setiap ditemukan fakta baru tentang masalah yang timbul akan selalu dilakukan investigasi, analisa dan menawarkan solusi jangka pendek. Seharusnya hal ini bisa diminimalisir ketika ternyata masalah yang teridentifikasi masih memiliki kesamaan atau kemiripan dengan kasus lain. Meskipun pada masing - masing produk memiliki karakter yang berbeda namun secara prinsip dapat ditarik kesimpulan secara umum yang dapat dijadikan milestone dalam kajian - kajian selanjutnya. Dengan demikian para tenaga ahli dalam setiap unit dapat berhemat waktu.

2. Pemborosan material

Dengan adanya investigasi dan analisa yang mengarah kepada masalah formulasi sebagai root cause maka harus dilakukan validasi dan verifikasi baik itu mengenai identifikasi masalah maupun dalam rangka mencari solusi. Tentu hal ini menelan biaya yang tidak sedikit. Sistem informasi memberikan solusi untuk membantu para ahli menentukan sikap dengan tepat.

Keluhan yang disampaikan oleh pelanggan tidak dapat serta merta ditangani secara teknis. Harus dilakukan validasi bahwa benar terjadi penyimpangan kualitas. Selain itu verifikasi juga harus dilakukan untuk memastikan kebenaran laporan yang sifatnya lebih kepada penyamaan persepsi yaiitu dengan melakukan simulasi sedekat mungkin dengan kondisi di lapangan. Material berupa barang jadi dan bahan baku simulasi bukanlah biaya yang murah yang harus ditanggung perusahaan. Setelah masalah teridentifikasi, maka percobaan laboratorium dilakukan untuk menemukan akar permasalahan dan solusi yang efektif.

3. Pengembangan produk yang lambat Oleh karena alasan - alasan di atas yang disebabkan adanya perulangan masalah, maka waktu yang seharusnya digunakan untuk melakukan pengembangan produk sedikit banyak terganggu. Mungkin hal ini tidak begitu membuat risau beberapa perusahaan kecil. Namun untuk perusahaan berskala nasional atau regional tentu saja ini merupakan masalah lain yang harus dipertimbangkan.

4. Kualitas produk tidak stabil

Akibat dari perubahan yang terus menerus dilakukan terhadap formula produk tertentu maka menimbulkan resiko pergeseran kualitas pada produk terkait. Masa percobaan yang relatif singkat demi mewujudkan short service time mengakibatkan formula tidak valid. 
5. Kehilangan kepercayaan

Kehilangan kepercayaan pelanggan adalah mimpi buruk bagi suatu perusahaan. Kekecewaaan terhadap kualitas barang yang disusul dengan buruknya penanganan keluhan pelanggan sangat mempengaruhi menurunnya tingkat kepercayaan pelanggan. Sistem informasi mengenai penanganan keluhan pelanggan berperan besar dalam mempertahankan kepercayaan ini.

6. Omzet menurun

Jika penurunan kepercayaan berlanjut maka yang terjadi kemudian adalah menurunnya omzet baik dalam jangka pendek dalam rangka penyelesaian masalah maupun jangka panjang yang didasarkan pada prinsip kehati hatian pelanggan.

\section{Landasan Teori}

Artificial Intelligence (AI) didefinisikan sebagai acting rationally dengan pendekatan rational agent (Suyanto,2014). Hal ini berdasarkan pemikiran bahwa komputer bisa melakukan penalaran secara logis dan juga bisa melakukan aksi secara rasional berdasarkan hasil penalaran tersebut.

Pengetahuan adalah kekuatan pendukung AI. Pengetahuan pada komputer berasal dari data yang ditanamkan manusia ke dalam sistem yang kemudian disebut knowledge engineering (merekayasa pengetahuan). Selanjutnya berpikir rasional menjadi kunci AI sebab inilah satu satunya cara untuk melakukan aksi secara rasional.

Dalam upaya merekayasa pengetahuan dapat dilakukan dengan memanfaatkan teknologi jaringan terutama jika cakupan perusahaan adalah skala nasional atau regional bahkan internasional. Setiap cabang suatu perusahaan dapat membangun sendiri sistem
$\mathrm{CCH}$ dalam jaringannya, dan serta merta dapat ikut membangun sistem dengan merekayasa pengetahuan untuk sistem yang lebih luas. Oleh karenanya dibutuhkan sebuah komunikasi antar server lokal agar dapat diakses dan dikontrol oleh pusat. Teknologi WAN (Wide Area Network) menjadi solusi untuk ini. WAN berukuran besar dan biasanya melibatkan campur tangan provider atau pemerintah sebagai penyedia infrastruktur jaringan (Sofana,2011). Ini merupakan konsekuensi yang sangat logis. Karena tidak mungkin pengguna personal mampu menyediakan kabel - kabel dan peralatan yang menghubungkan network seukuran sebuah negara atau bahkan lebih besar lagi.

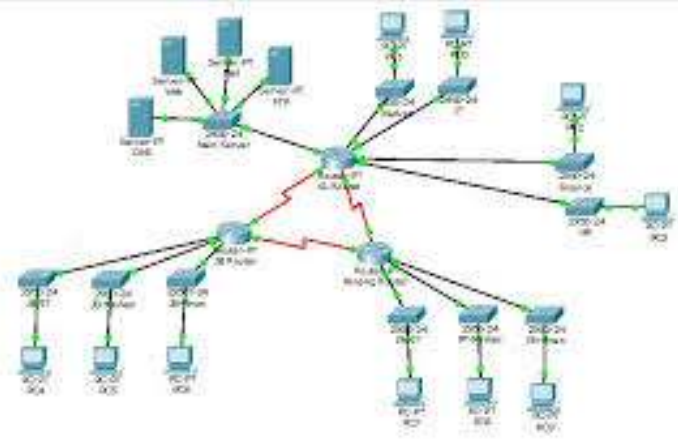

Gambar 4. WAN (Wide Area Network)

Data - data yang berasal dari seluruh cabang yang ada mungkin tidak disimpan secara sentral di sebuah server tunggal di pusat. Alternatif ini dalam rangka efisiensi kinerja server. Namun demikian data - data yang saling terhubung melalui server lokal dapat dipandang sebagai gudang data yang jika disatukan menjadi satu sistem basis data yang sangat besar. Gudang data (datawarehouse) merupakan suatu sistem manajemen basis data rasional (RDMS) yang didesain khusus untuk memenuhi kebutuhan akan sistem pengolahan transaksi (Hermawaty,2013).

Menurut Bill Inmon dalam Herawaty ada empat karakteristik data warehouse, yaitu :

1. Subject oriented 
Data diorganisasi menurut subyek dari aplikasi, misalnya sebuah perusahaan asuransi menggunakan data warehouse yang mengorganisasi data mereka sebagai pelanggan, premi dan klaim, daripada dengan produk - produk berbeda (otomotif, jiwa, dsb). Data diatur oleh subyek yang hanya mengandung informasi yang diperlukan untuk pengolahan pendukung keputusan.

2. Integrated

Ketika data menempati aplikasi aplikasi yang terpisah dalam lingkungan operasional, pengkodean data seringkali tidak konsisten. Contoh dalam merepresentasikan jenis kelamin, di lingkungan operasinal dibedakan sebagai "pria, wanita" tetapi data warehouse ketika menerima informasi jenis kelamin akan mengasumsikan pada istilah baku misalnya dengan " 0,1 ". Ini baru akan terjadi ketika data dipindahkan dari lingkungan operasional ke dalam data warehouse.

3. Time variant

Data warehouse terdiri dari suatu tempat untuk menyimpaan data yang berusia 5 sampai 10 tahun atau bahkan lebih lama untuk digunakan sebagai komparasi, trend dan peramalan. Data data ini tidak diupdate.

4. Non volatile

Data yang dimiliki tidak diperbaharui setelah berada di data warehouse, hanya dimuat dan diakses.

Dalam proses investigasi dan analisa, setiap keluhan yang diterima dari pelanggan akan diuji dengan algoritma berupa pertanyaan pertanyaan rasional guna menentukan root cause atau akar masalah. Ini sangat penting agar penanganan tetap fokus dan tepat sasaran. Hasil investigasi yang tepat akan menghasilkan identifikasi masalah yang jelas. Identifikasi masalah yang bias akan mempersulit analisa solusi. Di kesempatan yang berbeda masalah semacam ini dapat diselesaikan dengan bantuan metode fuzzy logic. Penerimaan keluhan hingga teridentifikasinya masalah dengan jelas dapat dilakukan dengan salah satu metode dalam teknik data mining yaitu dengan metode pohon keputusan (Classification And Regression Trees $=C A R T$ ). Dengan metode ini diperlukan adanya data history yaitu kumpulan data yang berasal dari data warehouse yang sifatnya non volatile atau tetap sebagai pembanding ataupun studi.

Data historis disebut juga data latihan atau data pengalaman (Susanto et.al,2010). Disebut demikian sebab sistem menggunakan data tersebut untuk latihan agar mendapatkan pengetahuan. Disebut pengalaman karena data tersebit berasal dari masa lampau yang tidak berubah, bahkan setiap hasil dari pengetahuan baru akan direkam sebagai pengalaman baru. Hal ini sejalan dengan pendekatan kemanusiaan bahwa pengetahuan akan semakin kaya dengan bertambahnya pengalaman. Dalam hal ini sistem komputer bertambah pengalaman dengan bertambahnya data. Semakin banyaknya pengetahuan yang diterima sistem, maka usaha untuk membangun AI semakin mudah sebab bisa dianalogikan bahwa sistem memiliki pengetahuan yang dekat dengan pengetahuan manusia yang selanjutnya diharapkan dapat berbuat layaknya manusia (acting rationally).

Ketika sistem mencoba mencari solusi solusi yang dianggap rasional dan logis, ada teknik penting dalam AI yang mendukung kegiatan ini, yaitu reasoning (penalaran). Penalaran adalah teknik penyelesaian masalah dengan cara merepresentasikan masalah ke dalam basis pengetahuan (knowledge base) menggunakan logic atau bahasa formal, yaiitu bahasa yang dipahami komputer (Suyanto,2014). Ada tiga buah logic yang dapat digunakan untuk merepresentasikan pengetahuan dan melakukan penalaran, yaitu logika proposisi (propositional logic), kalkulus 
predikat ( predicate calculus / first order logic), dan logika samar (fuzzy logic). Dua logika pertama digunakan untuk masalah yang memiliki kepastian, sedangkan satu lainnya untuk menyelesaikan masalah yang memiliki ketidakpastian (uncertainly). Memiliki ketidakpastian tidak sama dengan tidak memiliki kepastian. Logika samar membantu penyelesaian masalah ketika ditemukan masalah yang memenuhi kondisi pasti dan tidak pasti.

Usaha membangun AI yang juga penting adalah merekayasa pengetahuan. Seorang perekayasa pengetahuan harus memiliki pengetahuan yang cukup mengenai (Suyanto,2014) :

1. Domain pertanyaan, untuk merepresentasikan obyek dan hubungan antar obyek. Ini sangat berguna ketika menerapkannya dalam usaha membangun algoritma investigasi dan analisa.

2. Bahasa representasi, untuk mengkonversi fakta - fakta yang ada sehingga dapat dipahami baik komputer maupun manusia.

3. Implementasi prosedur inferensi, sehingga proses reasoning bisa dilaksanakan dengan cepat.

Kegiatan data mining dapat dikelompokkan menjadi dua yakni interpretasi dan prediksi (Vercellis, 2009). Interpretasi dilakukan dengan maksud mempelajari pola pada data yang dimiliki untuk selanjutnya dituangkan ke dalam aturan - aturan dan kriteria yang lebih mudah dipahami, kegiatan ini biasa digunakan untuk mempertahankan loyalitas konsumen. Prediksi dimaksudkan untuk membangun sebuah sistem antisipasi terhadap nilai dari suatu variabel acak yang akan terjadi di kemudian hari. Prediksi sangat membantu perusahaan untuk mempelajari peluang bisnis yang mungkin bisa diraih dan atau untuk meningkatkan profitabilitas dengan meningkatnya jumlah konsumen.

\section{Pembahasan}

Dalam persaingan bisnis yang semakin ketat diperlukan tindakan efektif dalam mengembangan bisnis yang berjalan. Perkembangan teknologi informasi yang begitu pesat memaksa para pelaku bisnis untuk beralih kepada era baru informasi. Era di mana memposisikan peran manusia sebagai manager meskipun masih banyak yang salah mengaplikasikan teknologi ini sehingga yang terjadi adalah menempatkan teknologi sebagai goal utama. Hal ini akan menyebabkan efisiensi yang semula diharapkan menjadi bias. Oleh karena ketidakmampuan manusia untuk beradaptasi dengan komputer justeru yang terjadi kemudian adalah seolah-olah komputer mengatur manusia. Yang harus diperhatikan adalah mengetahui metode - metode yang tepat dalam mengambil langkah penyelesaian masalah, merepresentasikan dan mengkonversi ke dalam bahasa formal. Di sini diperlukan peran seorang knowledge engineer yang dapat menjembatani komunikasi dua domain yang berseberangan.

Berbagai masalah yang timbul diinvestigasi dengan mengajukan pertanyaan. Dengan metode CART atau pohon keputusan maka terlebih dahulu ditentukan domain pertanyaan yang dirasa logis dan rasional. Diperlukan tenaga ahli di bidangnya untuk berdiskusi lebih banyak dengan perekayasa pengetahuan. Jumlah materi pertanyaan akan selalu bertambah dengan semakin banyaknya masalah yang ditemukan. Inilah karakter data yang disebut non-volatile, tidak berubah, hanya bertambah dan harus dapat diakses kapanpun tanpa terbatas oleh waktu. Cakupan bahasan harus dibatasi guna mempertahankan efektifitas penanganan.

Dalam industri coating terdapat banyak kategori jika dilihat dari sudut pandang bahan dasar, misalnya : 
1. Nitrocellulose

2. Alkyd

3. Acrylic

4. Polyurethane

5. Ultra violet curing

6. Polyester

7. Epoxy

Atribut - atribut di atas masih perlu disandingkan dengan atribut lain guna mempersempit bahasan antara lain :

A. Pelarut : air (waterbased), minyak (solvent based).

B. Paket : 1 komponen, 2 komponen, 3 komponen

C. Substrat : kayu, konkret/ tembok, metal, plastik, kaca, keramik

Sehingga dapat diambil contoh salah satu produk coating $\mathrm{XXX}$ adalah produk cat (coating) minyak polyurethane 2 komponen untuk mobil (metal). Salah satu atribut berubah maka penanganan dan identifikasi masalah yang mungkin timbul pun akan berbeda, misalnya untuk produk $\mathrm{ABC}$ yaitu cat minyak polyurethane 2 komponen untuk furniture (kayu). Mengapa demikian sebab setiap produk didesain untuk memenuhi kebutuhan yang berbeda.

Dalam menentukan calon pertanyaan di pohon keputusan yang selanjutnya dapat dibuat menjadi sebuah rule, harus dilakukan dengan memperhatikan karakter produk (obyek) dan klasifikasi yang akan dicapai. Masalah dalam industri coating pun masih harus diidentifikasi dengan klasifikasi antara lain :

1. Cairan cat

a. Kemasan

b. Fisik cairan
i. Menggumpal
ii. Memisah
iii. Bau (bakteri)
iv. Kering
v. Berubah warna
vi. Kekentalan

2. Aplikasi cat a. Proses
i. Lingkungan
ii. Metode aplikasi
iii. Persiapan

b. Hasil aplikasi
i. Adhesi
ii. Kilap
iii. Daya tutup
iv. Waktu kering
v. Kekerasan
vi. Kehalusan

Sedangkan dalam tahap analisa, hasilnya dapat diklasifikasi antara lain :

1. Manusia : kelalaian manusia

2. Mesin : penggunaan mesin yang tidak sesuai, kerusakan, malfunction

3. Metode : metode yang tidak sesuai

4. Material : bahan baku yang dipakai, perubahan desain formula, pergantian bahan baku, sifat fisik/kimia produk itu sendiri

5. Non teknis : berkenaan dengan sosial, budaya, hubungan emosional

Sejauh mana komputer mampu membantu manusia menyelesaikan masalah - masalah klasifikasi tersebut di atas sangat bergantung pada penyematan pengetahuan kepada komputer yang dilakukan oleh perekayasa pengetahuan. Database kini bukan sekedar berisi data secara harfiah, namun sudah berupa pengetahuan atau knowledgebase. Dengan mengandalkan data pengalaman yang valid maka kegiatan data mining untuk mewujudkan AI dapat berjalan dengan baik. Data latihan secara langsung diperoleh dari laporan keluhan. 


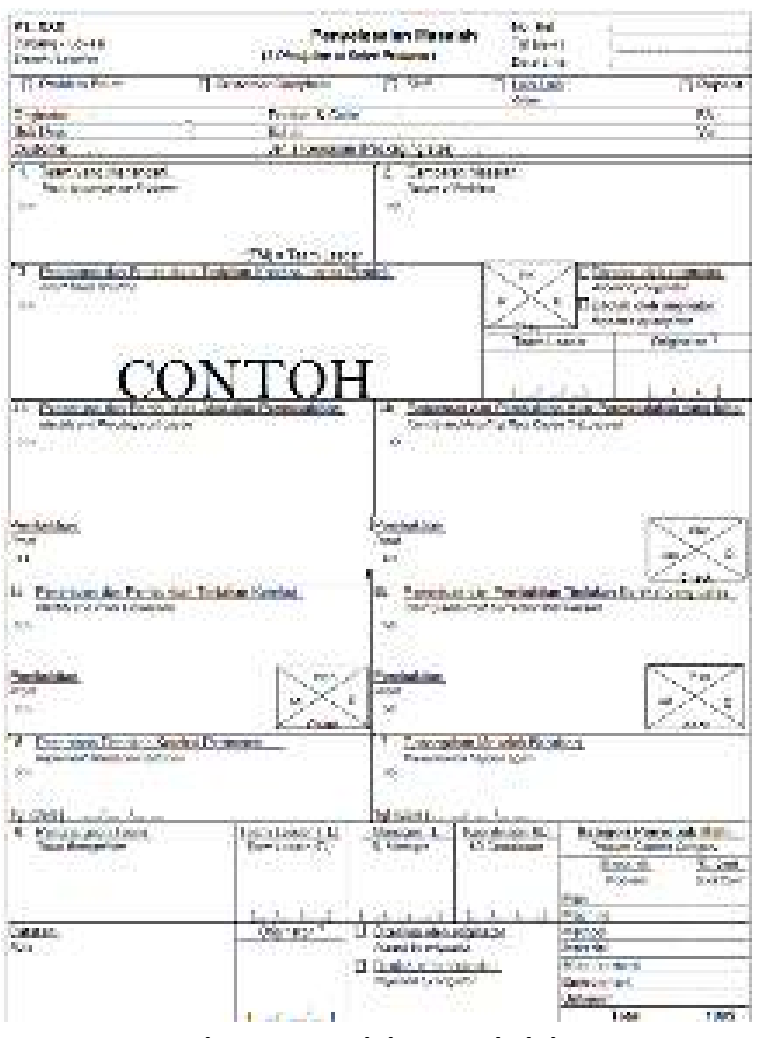

Gambar 5. Contoh laporan keluhan

Laporan keluhan yang telah terbukti dapat diselesaikan dan diterima pelanggan dengan baik menjadi aset penting bagi pengembangan produk. Memperhatikan potensi masalah yang dapat timbul kemudian dapat dipelajari demi menghindari perulangan masalah dan tentu hal ini akan meningkatkan efisiensi kerja secara umum. Dari sisi frontliner misalnya sales marketing representatif pun mendapatkan pelajaran berharga jika saja bersedia meluangkan kesempatan untuk ikut andil dalam proses penanganan masalah. Namun hal ini sulit terwujud oleh karena bisa jadi bertolak belakang dengan latar belakang keterampilan yang dikuasai, dan selain itu mengejar target penjualan masih menjadi pilihan.

Metode CART yang digunakan adalah kegiatan berulang (rekursi) yakni dilakukan pengujian terus menerus hingga didapatkan simpul - simpul keputusan. Rekursi ini berlaku untuk semua tahapan penyelesaian masalah.
Sedangkan alur kerja penyelesaian masalah dapat diilustrasikan sebagai berikut.

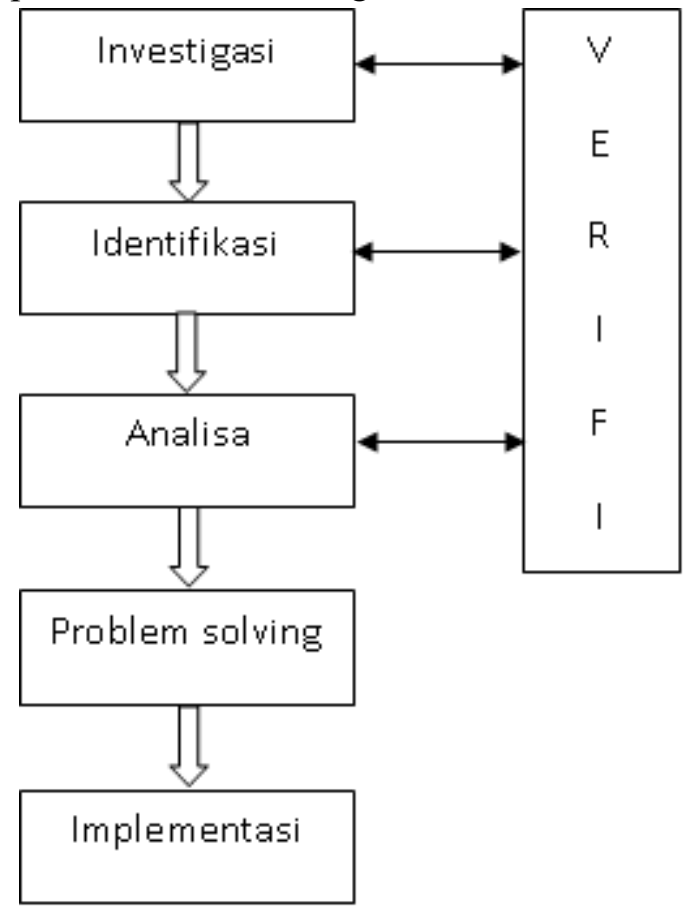

Gambar 6. Flowchart penyelesaian masalah

\section{Investigasi}

Algoritma yang dapat diterapkan dapat memanfaatkan logika proporsional sederhana ifthen. Dalam tahap investigasi menggunakan metode CART maka diperlukan data pembanding mengenai potensial masalah/ resiko yang mungkin terjadi dan dapat diterima secara rasional. Data primer sebagai pedoman dalam pelaksanaan investigasi harus divalidasi dan diverifikasi agar memenuhi syarat dalam tahap selanjutnya, yaitu identifikasi masalah.

Informasi - informasi penting yang harus dipenuhi dalam tahapan ini misalnya :

1. Nama produk

2. Nomor batch

3. Nama customer

4. Step aplikasi 


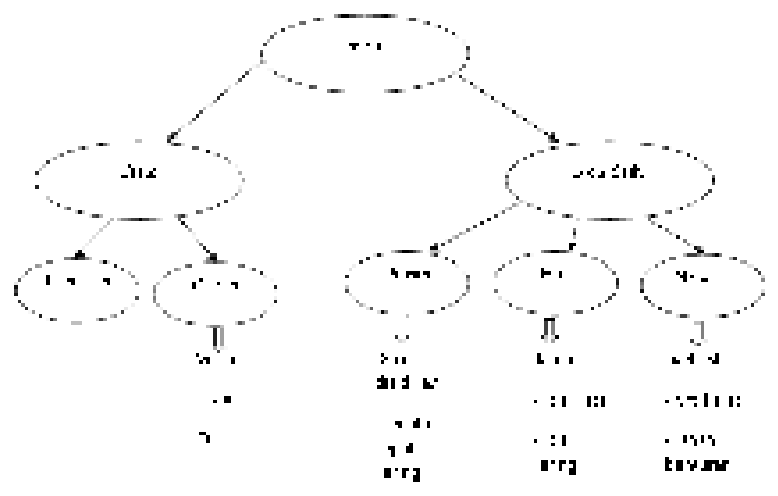

Gambar 7. Contoh investigasi (initial)

\section{Identifikasi}

Tujuan dari tahapan identifikasi adalah menentukan masalah secara tepat sesuai dengan fakta - fakta yang disajikan, dengan persepsi yang sama antara pelanggan dan tim kerja $\mathrm{CCH}$. Seringkali pelanggan tidak dapat menjelaskan secara tepat apa sebenarnya yang terjadi sehingga diperlukan data untuk menentukannya. Kesalahan identifikasi berkibat fatal pada proses selanjutnya. Beberapa pelanggan ada yang dapat memberikan keterangan lebih baik kepada tim $\mathrm{CCH}$, namun sekali lagi diperlukan verifikasi mengenai hal ini. Sekali identifikasi masalah menemui golnya maka seluruh kegiatan pemecahan masalah merujuk kepada hasil tersebut. Domain pekerjaan menjadi lebih sempit dan terarah.

Masih menggunakan metode CART, pencabangan untuk menentukan klasifikasi memegang peran penting menuju keakuratan hasil. Digunakan atribut - atribut atau ciri - ciri spesifik dari setiap resiko untuk menentukan klasifikasi dengan benar.

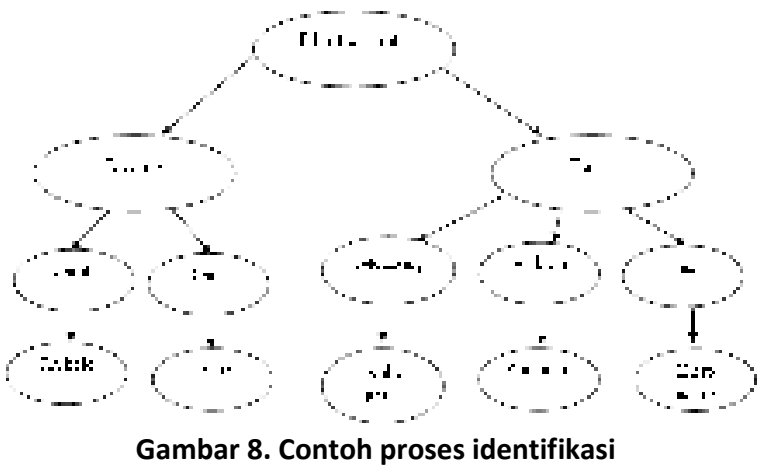

Analisa

Tahapan selanjutnya adalah analisa, di mana algoritmanya mungkin akan menjadi lebih rumit dari dua tahap sebelumnya. Akan ada lebih banyak pertanyaan yang berperan sebagai splitter (Susanto et.al.,2010) dalam menentukan klasifikasi. Hal ini wajar dikarenakan besarnya data latihan yang harus dipakai guna mendapatkan hasil yang akurat. Di tahapan ini sistem telah memiliki data latihan berupa laporan penanganan masalah yang berhasil diselesaikan dari seluruh masalah yang pernah dilaporkan. Dengan teknik filtering sederhana maka dengan cepat dapat diteliti cara penanganan yang dianggap sesuai berdasarkan kesamaan hasil identifikasi masalah, ataupun kesamaan karakter produk. Sangat mungkin adopsi penyelesaian masalah dari produk yang berbeda namun dengan masalah yang identik atau sebaliknya.

Apabila solusi awal tidak mungkin diambil, maka sistem akan melanjutkan dengan pengolahan data, yakni mencoba mengambil pengetahuan dari data latihan yang telah dimiliki sebelumnya. Algoritma dari kegiatan ini masih menggunakan hasil pengolahan data di tahapan sebelumnya.

Untuk dapat melaksanakan tahapan tahapan tersebut di atas maka $\mathrm{CCH}$ harus memiliki kebebasan akses yang cukup. Dalam rangka analisa masalah, mereka mungkin saja berkomunikasi dengan unit distribusi, 
pengemasan, warehouse, proses produksi, QC, atau bahkan R\&D.

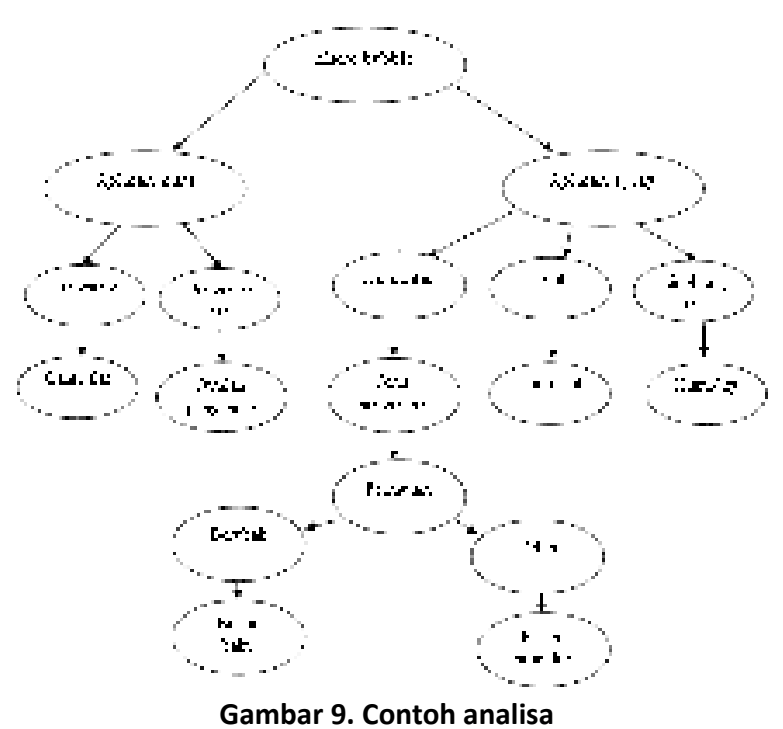

\section{Implementasi}

Solusi yang dihasilkan sistem AI mungkin saja tidak mencapai tingkat kepercayaan yang tinggi sehingga tidak dapat serta merta diterapkan. Implementasi dari hasil operasi oleh sistem AI dilakukan di laboratorium untuk mendapatkan verifikasi dengan tingkat kepercayaan mendekati $100 \%$. Bedanya dngan cara konvensional adalah laboratorium langsung melakukan percobaan yang hasilnya sudah dapat diprediksi. Dengan demikian hasil yang diperoleh tidak akan menjadi bias atau terlalu banyak alternatif yang dengannya akan menambah kompleks dalam mengambil keputusan. Di sinilah peran manusia sebagai pengambil keputusan yang memegang kendali atas sistem AI.

\section{Kesimpulan}

Data warehouse yang berasal dari laporan penyelesaian masalah seluruh cabang dapat dimanfaatkan untuk membangun sebuah sistem cerdas. Data - data tersebut digunakan sebagai data latihan atau data histori yang membantu mencari solusi dengan tepat dan bersifat non volatile. Data hanya bisa ditambah dan diakses. Peran manusia masih sangat dominan meskipun sistem cerdas yang dibangun telah dapat memberikan solusi di setiap tahapan penyelesaian masalah.

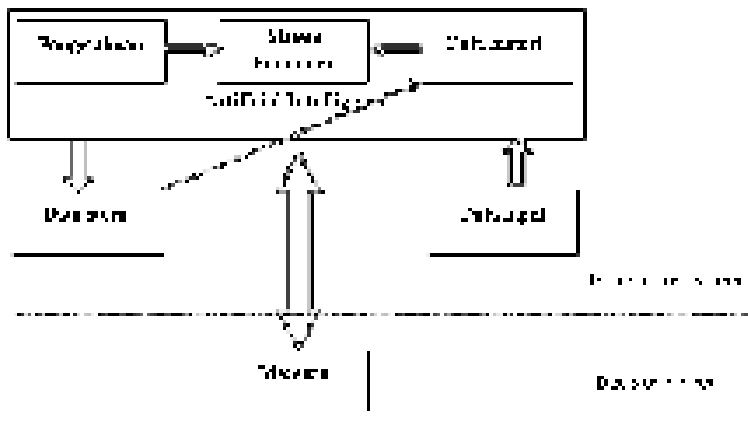

Gambar 10. Skema Artificial Intelligence

\section{Saran}

Penelitian ini difokuskan pada penyelesaian masalah dengan metode CART di mana memerlukan banyak iterasi ketika komplain yang muncul lebih kompleks. Mungkin saja metode lain dalam konsep data mining lebih efektif dalam membangun sebuah sistem cerdas AI sehingga tidak memerlukan space memory yang relatif besar dan juga mempersingkat waktu proses.

\section{DAFTAR PUSTAKA}

Kusrini; Luthfi, Emha Taufik, (2009) Algoritma Datamining, Andi Publisher, Yogyakarta

Vercellis; Carlo, (2009) Business

Intelligence: Data Mining and Optimization for Decision Making Oded Maimon · Lior Rokach Data Mining and Knowledge : Discovery Handbook, Springer-Verlag Berlin Heidelberg Witten,Ian H.; Frank, Iebe; Hall, Mark A.;(2011) Data Mining third edition; Elsevier, MA, USA

Gorunescu, Florin.(2011) Data Mining : Concepts,Models and Techniques, SpringerVerlag Berlin Heidelberg 
Hermawati, Fajar Astuti.(2013) Data

Mining, Penerbit Andi, Yogyakarta

Sofana, Iwan.(2011) Teori dan Modul

Praktikum Jaringan Komputer, Modula,

Bandung

Susanto,Sani.,Suryadi,Dedy.(2010)

Pengantar Data Mining, Penerbit Andi,

Yogyakarta

Suyanto.(2014) Artificial Intelligence,

Penerbit Informatika, Bandung

Wahyuni.(2004) Sistem Berkas, Penerbit

Andi, Yogyakarta 